\title{
OBITUARY
}

\section{STUART SPENCE MEIGHAN}

Ophthalmology in Glasgow has suffered a great loss by the sudden death of Dr. S. Spence Meighan on April 20, 1954, just 6 months after his retirement from hospital service. The son of Dr. T. Spence Meighan, Surgeon to the Glasgow Eye Infirmary, 1875-1909, he was educated at the Glasgow High School, and at Glasgow University, where he graduated in Science and in Medicine (with Honours) in 1912. After residentships with Sir William McEwan and Professor Ralph Stockman, he joined the staff of the Glasgow Eye Infirmary as a house surgeon in 1914, thereafter proceeding to France to join the Highland Field Ambulance under Col. Rorie in the 51st (Highland) Division. With this Unit he served until he was taken prisoner in March, 1918. His experience in one of the worst of the prisoner-of-war camps was to have a lasting effect upon his general health, and was to handicap him to some extent throughout his life. For his services in France he was twice mentioned in dispatches.

On demobilisation, he returned to the staff of the Glasgow Eye Infirmary, and in 1920 became a Fellow of the Royal Faculty of Physicians and Surgeons of Glasgow qua Ophthalmic Surgeon. He was later appointed ophthalmic surgeon to Stobhill Hospital, then a Poor Law Institution, and it was to him that the development of the ophthalmic department of this hospital is entirely due. In 1926 he was promoted surgeon to the Glasgow Eye Infirmary, and in the same year became professor of ophthalmology at the Anderson College of Medicine, a post which he held until a failure of health caused him to resign. He was, shortly afterwards, appointed an honorary lecturer in ophthalmology to the University of Glasgow.

He was vice-president of the Ophthalmological Society of the United Kingdom, a past president of the Scottish Ophthalmological Club, and at the time of his death vicepresident elect of the Section of Ophthalmology of the forth-coming British Medical Association meeting in Glasgow.

He was a member of the Northern Hospitals Board of Management, and became chairman of its Medical Committee. Transparently honest in all his dealings, the least self-seeking of men, he was an ideal chairman of the quiet type, and was able to guide many potentially troublesome committees to a wise compromise.

Dr. Meighan was a careful and skilful operator, whose care was for the patient first. It is a tribute to the man that he was at all times surrounded by a band of loyal assistants. There are many who owe to Meighan's kindly tuition their first introduction to a successful career in ophthalmology. An appearance of diffidence and uncertainty masked a sound clinical knowledge of his subject. It is true to say that there was no better consulting opinion in Glasgow than his. No one's advice and guidance was more often sought by those in trouble both personally or professionally, and never in vain.

His special professional interests lay in medical legal ophthalmology, and in the treatment of trachoma; his experience of this disease, in the only area of the United Kingdom in which it is notifiable, was unique - he was to have delivered a paper on this subject at the meeting of the B.M.A. Section of Ophthalmology in July, 1954.

One of the kindest of men, he was keloved both by colleagues and patients. He was blind to faults, and saw some good in everyone. He had a real sense of humour, which was used without malice to expose the poseur and the humbug. His exceptional memory for the spoken word and his gift of mimicry were a joy to those who knew him best, these gifts, perhaps, being best displayed when reporting on the proceedings of a recent scientific meeting. His vignettes of personalities would, however, have been appreciated even by the victims. Meighan's name will long be remembered in Glasgow. He is survived by his wife and two sons. 